\title{
An in vitro comparison of nickel and chromium release from brackets
}

\section{Ana Cristina Soares Santos \\ Haddad(a) \\ Andre Tortamano(b) \\ Alexandre Luís de Souza(c) \\ Pedro Vitoriano de Oliveira ${ }^{(\mathrm{d})}$}

(a) PhD Student; (b) Assistant Professor

- Department of Orthodontics, School of Dentistry, University of São Paulo, São Paulo, SP, Brazil.

(c) PhD Student; (d)Associate Professor

- Lab of Emission and Atomic Absorption Spectrometry, Institute of Chemistry, University of São Paulo, São Paulo, SP, Brazil.
Corresponding author:

Ana C. S. S. Haddad

Departamento de Ortodontia, Faculdade de

Odontologia, Universidade de São Paulo

Av. Prof. Lineu Prestes, 2227

São Paulo - SP - Brazil

CEP: 05508-000

E-mail:anacssantos@usp.br

Received for publication on Feb 18, 2009

Accepted for publication on May 25, 2009

\begin{abstract}
This study aimed at comparing amounts of nickel (Ni) and chromium $(\mathrm{Cr})$ released from brackets from different manufacturers in simulated oral environments. 280 brackets were equally divided into 7 groups according to manufacturer. 6 groups of brackets were stainless steel, and 1 group of brackets was made of a cobalt-chromium alloy with low Ni content $(0.5 \%)$. International standard ISO 10271/2001 was applied to provide test methods. Each bracket was immersed in $0.5 \mathrm{ml}$ of synthetic saliva (SS) or artificial plaque fluid (PF) over a period of 28 days at $37^{\circ} \mathrm{C}$. Solutions were replaced every 7 days, and were analyzed by spectrometry. The Kruskal-Wallis test was applied. Amounts of Ni release in SS ( $\mu \mathrm{g} \mathrm{L}^{-1}$ per week) varied between groups from "bellow detection limits" to 694 , and from 49 to 5,948.5 in PF. The group of brackets made of cobalt-chromium alloy, with the least nickel content, did not release the least amounts of Ni. Amounts of Cr detected in SS and in PF ( $\mu \mathrm{g} \mathrm{L}^{-1}$ per week) were from 1 to 10.4 and from 50.5 to 8,225 , respectively. It was therefore concluded that brackets from different manufacturers present different corrosion behavior. Further studies are necessary to determine clinical implications of the findings.
\end{abstract}

Descriptors: Orthodontic brackets; Nickel; Chromium; Saliva, artificial. 


\section{Introduction}

The corrosion process of metallic brackets has been linked to the deterioration of their mechanical properties and to adverse biological effects. ${ }^{1-8}$ Since none of these aspects are desirable in orthodontic practice, comparing amounts of metal release from commercially available brackets is necessary to determine their resistance to corrosion in the oral environment.

The American Iron and Steel Institute (AISI) types $316 \mathrm{~L}$ or 304 austenitic stainless steel alloys are currently used for bracket manufacturing., ${ }^{9,10}$ These steel alloys typically contain approximately $8 \%$ nickel $(\mathrm{Ni})$ and $18 \%$ chromium $(\mathrm{Cr})$ with a small amount of manganese and silicon, and a low carbon content (less than $0.1 \%$ ). ${ }^{9} 10$ AISI type $316 \mathrm{~L}$ also contains 2 to $3 \%$ molybdenum..$^{9,10}$ Besides that, bracket manufacturing includes different processes with or without welding. Therefore, some brackets may be a layered complex of alloys differing in composition and mechanical state as various parts may be welded or brazed together. ${ }^{10}$

As a group, the cobalt-base alloys may be generally divided in three categories described as wearresistant, corrosion-resistant and heat-resistant materials. ${ }^{11}$ Cobalt-base wear-resistant alloys contain the least Ni content ( $3 \% \max ), 25$ to $30 \% \mathrm{Cr}, 0.25$ to $3.3 \%$ carbon, and also manganese, silicon, molybdenum, tungsten, iron and sodium. ${ }^{11}$ This alloy is used in bracket manufacturing. However, although the cobalt-base wear-resistant alloys (with low $\mathrm{Ni}$ content) exhibit some resistance to aqueous corrosion, it is limited. ${ }^{11}$ To satisfy the industrial need for alloys that exhibit higher resistance to aqueous corrosion, it was necessary to increase Ni content $(9$ to $35 \%)$, and decrease carbon content $(0.8 \% \max )$ in the cobalt-base corrosion-resistant alloys. ${ }^{11}$ The third category of cobalt-base alloys, the high-temperature alloys, is used in industry. ${ }^{11}$

This study aimed at comparing amounts of $\mathrm{Ni}$ and $\mathrm{Cr}$ released from various bracket models from different manufacturers in simulated oral environments over a period of 28 days.

\section{Material and Methods}

The sample comprised 280 orthodontic brackets of upper premolars from the $\mathrm{MBT}^{\mathrm{TM}}$ prescription. ${ }^{12}$ The brackets were equally divided into 7 groups from different models and manufacturers as follows: Kirium Line ${ }^{\mathrm{TM}}$ Abzil $^{\mathrm{TM}}$ (São José do Rio Preto, SP, Brazil - code: 288-133), Mini Master Series ${ }^{\text {TM }}$ American Orthodontics ${ }^{\mathrm{TM}}$ (Sheboygan, WI, USA - code: $390-0027)$, Discovery ${ }^{\mathrm{TM}}$ Dentaurum $^{\mathrm{TM}}$ (Ispringen, Baden-Württemberg, Germany - code: 790118-00), Full Size ${ }^{\mathrm{TM}}$ Unitek $^{\mathrm{TM}}$ (Monrovia, CA, USA - code: 119-936), Morelli M.B.T. ${ }^{\mathrm{TM}}$ Morelli $^{\mathrm{TM}}$ (Sorocaba, SP, Brazil - code: 10-35-007), NuEdge ${ }^{\mathrm{TM}}$ TP Orthodontics $^{\text {TM }}$ (LaPorte, IN, USA - code: 293-205), and Victory ${ }^{\mathrm{TM}}$ Unitek $^{\mathrm{TM}}$ (Monrovia, CA, USA - code: 017-890). The different brackets studied were labeled A to G respectively according to the model/ manufacturer. The brackets were made of stainless steel (approximately $8 \% \mathrm{Ni}$ and $18 \% \mathrm{Cr}$ ), except for the $\mathrm{F}$ brackets which were of cobalt-chromium alloy with low $\mathrm{Ni}$ content $(0.5 \% \mathrm{Ni}){ }^{9,11}$ The brackets were tested in an "as-received" state, and complied with the requirement of "no visible signs of change or deterioration". The base of the brackets was not covered with resin, thus eliminating the possibility of extraneous sources of $\mathrm{Ni}$ and $\mathrm{Cr}$.

Brackets from each manufacturer were divided into four groups of 10 specimens. An initial corrosion test was carried out on 10 brackets from each manufacturer immersed in synthetic saliva, and 10 brackets from each manufacturer immersed in artificial plaque fluid. An identical corrosion test was performed on the other 20 brackets immersed in the same solutions 30 days later.

International standard ISO 10271/2001, "Dental metallic materials - corrosion test methods", was applied to provide test methods. ${ }^{13}$

$\mathrm{Ni}$ and $\mathrm{Cr}$ release from brackets, comprising the sample, was quantified by means of a static immersion test. The studied brackets had no contact with metallic materials during the test and each bracket was placed in a separate polypropylene tube (Axigen $^{\mathrm{TM}}$, Union City, CA, USA) containing $0.5 \mathrm{ml}$ of synthetic saliva or artificial plaque fluid. The simulated saliva medium was synthesized on the basis of the formula of Leung and Darvell. ${ }^{14}$ The final $\mathrm{pH}$ was $6.7 \pm 1$. Artificial plaque fluid was prepared by dissolving $10.0 \pm 0.1 \mathrm{~g} 90 \%\left(\mathrm{~m} \mathrm{~m}^{-1}\right) \mathrm{C}_{3} \mathrm{H}_{6} \mathrm{O}_{3}$ and 
$5.85 \pm 0.005 \mathrm{~g} \mathrm{NaCl}$ in approximately $300 \mathrm{ml}$ of water, and then by adjusting volume to $1,000 \pm 10 \mathrm{ml}$ with distilled water. The final $\mathrm{pH}$ was $2.3 \pm 1$. The container was closed to prevent evaporation of the solution, and the sample tubes were stored at $37^{\circ}$ C for 28 days. Every 7 days \pm 1 h brackets were removed from each tube, and placed in other tubes with fresh immersion solution. Furthermore, 3 tubes containing the solution prepared at each experimental period, but with no brackets, were used as controls, and were stored exactly as the sample tubes were.

The solutions inside each tube at each experimental period were analyzed by spectrometry to determine $\mathrm{Ni}$ and $\mathrm{Cr}$ content. All synthetic saliva samples and artificial plaque fluid samples from controls and from $\mathrm{C}$ and $\mathrm{G}$ brackets were analyzed by simultaneous graphite furnace atomic absorption spectrometry (SIMAAS), model SIMAA 6000 (Perkin Elmer Life and Analytical Sciences ${ }^{\mathrm{TM}}$, Shelton, CT, USA), equipped with longitudinal Zeeman-effect background correction, Echelle optical arrangement, and solid-state detector. All solutions were fed into the graphite tube by means of an AS72 autosampler (Perkin Elmer Life and Analytical Sciences $\left.^{\mathrm{TM}}\right)$. Argon $99.996 \%\left(\mathrm{v} \mathrm{v}^{-1}\right)\left(\right.$ White Martins $^{\mathrm{TM}}$,
São Paulo, SP, Brazil) was used as the purge gas. The instrumental setting-up conditions are shown in Table 1. Artificial plaque fluid samples from A, $\mathrm{B}, \mathrm{D}, \mathrm{E}$, and $\mathrm{F}$ brackets presented high concentrations of $\mathrm{Ni}$ and $\mathrm{Cr}$. In this case, determination of $\mathrm{Ni}$ and $\mathrm{Cr}$ was not possible by SIMAAS, since several dilutions would have been necessary, decreasing accuracy. Therefore, levels of $\mathrm{Ni}$ and $\mathrm{Cr}$ were determined by inductively coupled plasma optical emission spectrometry (ICP OES), model Spectro Ciros $\mathrm{CCD}^{\mathrm{m}}$ (Spectro Analytical Instruments $\mathrm{GmbH} \&$ Co. ${ }^{\mathrm{T}}$, Kleve, Germany). The instrumental settingup conditions are shown in Table 2. The detection limits of SIMAAS and ICP OES were calculated based on calibration curves. For SIMAAS, the detection limits for the synthetic saliva samples $(\mu \mathrm{g}$ $\mathrm{L}^{-1}$ ) were 2.78 for $\mathrm{Ni}$ and 0.27 for $\mathrm{Cr}$; for the artificial plaque fluid samples $\left(\mu \mathrm{g} \mathrm{L}^{-1}\right)$, the detection limits were 2.77 for $\mathrm{Ni}$ and 0.85 for Cr. For ICP OES, the detection limits were the same $\left(0.4 \mu \mathrm{g} \mathrm{L}^{-1}\right)$ for both elements.

The Ni and $\mathrm{Cr}$ released values from 7 different groups of brackets immersed in 2 different solutions over a period of 28 days were analyzed using the Kruskal-Wallis test and the non-parametric multiple comparison test. Tests were performed with a $5 \%$
Table 1 - Instrumental setting for determination of $\mathrm{Cr}$ and $\mathrm{Ni}$ release in synthetic saliva and artificial plaque fluid by SIMAAS-6000.

\begin{tabular}{|c|c|c|c|c|}
\hline \multicolumn{3}{|c|}{ Element } & $\mathrm{Cr}$ & $\mathrm{Ni}$ \\
\hline \multicolumn{3}{|l|}{ Wavelength } & $232.0 \mathrm{~nm}$ & $357.0 \mathrm{~nm}$ \\
\hline \multicolumn{3}{|l|}{ Band pass } & $0.7 \mathrm{~nm}$ & $0.7 \mathrm{~nm}$ \\
\hline \multicolumn{3}{|l|}{ Lamp type* } & $\mathrm{HCL}$ & $\mathrm{HCL}$ \\
\hline \multicolumn{3}{|l|}{ Lamp current } & $25 \mathrm{~mA}$ & $25 \mathrm{~mA}$ \\
\hline \multicolumn{3}{|c|}{ Calibration range } & 2.5 to $20 \mu \mathrm{g} \mathrm{L}^{-1}$ & 0.1 to $0.8 \mu \mathrm{g} \mathrm{L}^{-1}$ \\
\hline \multicolumn{3}{|c|}{ Signal measurements } & Peak area (AA-BG) & \\
\hline \multicolumn{3}{|c|}{ Standard and sample volume } & $10 \mu l$ & \\
\hline \multicolumn{3}{|c|}{ Standard and sample replicates } & 3 & \\
\hline \multicolumn{5}{|c|}{ Heating program for SIMAAS } \\
\hline Step & $\mathrm{T}\left({ }^{\circ} \mathrm{C}\right)$ & $\operatorname{Ramp}(\mathrm{s})$ & Hold (s) & $\operatorname{Ar}\left(\mathrm{mL} \mathrm{min}^{-1}\right)$ \\
\hline Dry I & 110 & 10 & 15 & 250 \\
\hline Dry II & 130 & 1 & 10 & 250 \\
\hline Pyrolysis & 1,300 & 10 & 20 & 250 \\
\hline Atomization** & 2,400 & 0 & 5 & 0 \\
\hline Cleaning & 2,500 & 1 & 3 & 250 \\
\hline
\end{tabular}

${ }^{*} \mathrm{HCL}$ : Hollow Cathode Lamp; ${ }^{* *}$ Read time. 
level of significance. Values below the detection limits were subject to statistical analysis, even if inaccurate, having been estimated by the apparatus. In the tables, however, these values are referred to as "below detection limits" $(<\mathrm{DL})$.

Table 2 - ICP operating conditions.

\begin{tabular}{l|c}
\hline \multicolumn{1}{c|}{ Generator } & Free-running at 27.12 MHz \\
\hline Power $(\mathrm{W})$ & 1400 \\
\hline Nebulizer & Cross-flow (Spectro) \\
\hline Spray chamber & Double pass, Scott-type \\
\hline Outer gas $\left(\mathrm{L} \mathrm{min}^{-1}\right)$ & 12 \\
\hline Intermediate gas $\left(\mathrm{L} \mathrm{min}^{-1}\right)$ & 1.0 \\
\hline Nebulizer gas $\left(\mathrm{L} \mathrm{min}^{-1}\right)$ & 1.0 \\
\hline Sample uptake rate $\left(\mathrm{ml} \mathrm{min}{ }^{-1}\right)$ & 1.5 \\
\hline \multirow{2}{*}{ Analytical wavelenght $(\mathrm{nm})$} & $\mathrm{Cr}(\mathrm{I}) 341.476$ \\
\cline { 2 - 2 } & $\mathrm{Ni}(\mathrm{I}) 205.552$ \\
\hline
\end{tabular}

(I): Atomic emission line.

\section{Results}

The mean weekly values for $\mathrm{Ni}$ and $\mathrm{Cr}$ release $(\mu \mathrm{g}$ $\mathrm{L}^{-1}$ ) from the studied brackets immersed in synthetic saliva and artificial plaque fluid over the experimental time and the data from the control group are presented in Table 3. Since the Kruskal-Wallis test was applied, median values were considered instead of mean values. The amount of $\mathrm{Ni}$ released in synthetic saliva ( $\mu \mathrm{g} \mathrm{L}^{-1}$ per week) varied between groups from $<$ DL (below detection limits) (C brackets) to 694 (A brackets); in artificial plaque fluid, it varied from 49 (C brackets) to 5,948.5 (E brackets). The group of brackets made of cobalt-chromium alloy $(\mathrm{F})$, with the least nickel content $(0.5 \%)$, did not release the least amounts of Ni. Amounts of Cr detected in synthetic saliva and in artificial plaque fluid $\left(\mu \mathrm{g} \mathrm{L}^{-1}\right.$ per week) were from 1 (D brackets) to 10.4 (F brackets) and from 50.5 (G brackets) to 8,225 (D brackets), respectively.

The $\mathrm{P}$ values obtained from the non-parametric multiple comparison test for $\mathrm{Ni}$ and $\mathrm{Cr}$ release in

Table 3 - Mean weekly values of $\mathrm{Ni}$ and $\mathrm{Cr}$ release $\left(\mu \mathrm{g} \mathrm{L}^{-1}\right)$ for different groups of brackets immersed in synthetic saliva and artificial plaque fluid.

\begin{tabular}{|c|c|c|c|c|c|c|c|c|c|}
\hline \multirow{2}{*}{ Brackets } & \multirow{2}{*}{ Solution } & \multicolumn{4}{|c|}{ Ni release } & \multicolumn{4}{|c|}{$\mathrm{Cr}$ release } \\
\hline & & Mean & SD & Median & $\mathrm{N}$ & Mean & SD* & Median & $\mathrm{N}$ \\
\hline \multirow{2}{*}{ A } & S & 597.76 & 289.49 & 694.00 & 80 & 13.39 & 11.55 & 10.00 & 80 \\
\hline & PF & $6,118.95$ & $3,942.51$ & $5,033.50$ & 80 & $6,733.90$ & $2,134.24$ & $6,395.50$ & 80 \\
\hline \multirow{2}{*}{ B } & S & 10.39 & 11.11 & 6.55 & 80 & 5.73 & 4.57 & 4.20 & 80 \\
\hline & PF & $1,731.08$ & 982.91 & $1,566.00$ & 80 & $3,590.30$ & $2,516.70$ & $3,286.00$ & 80 \\
\hline \multirow{2}{*}{ C } & S & 6.93 & 9.42 & $<\mathrm{DL}$ & 80 & 1.60 & 1.42 & 1.05 & 80 \\
\hline & PF & 237.83 & 446.83 & 49.00 & 80 & 102.60 & 79.58 & 74.00 & 80 \\
\hline \multirow{2}{*}{$\mathrm{D}$} & $S$ & 13.07 & 15.96 & 6.60 & 80 & 2.27 & 3.09 & 1.00 & 80 \\
\hline & PF & $6,999.11$ & $6,334.58$ & $4,035.00$ & 80 & $13,727.13$ & $11,691.77$ & $8,225.00$ & 80 \\
\hline \multirow{2}{*}{$E$} & $S$ & 54.28 & 46.62 & 35.85 & 80 & 6.84 & 8.26 & 3.90 & 80 \\
\hline & PF & $5,960.30$ & $4,390.25$ & $5,948.50$ & 80 & $6,867.76$ & $4,607.71$ & $7,381.50$ & 80 \\
\hline \multirow{2}{*}{$\mathrm{F}$} & S & 14.17 & 15.08 & 8.95 & 80 & 13.17 & 7.43 & 10.40 & 80 \\
\hline & PF & $1,570.48$ & $1,221.76$ & $1,514.50$ & 80 & $2,472.35$ & $1,958.00$ & $2,314.50$ & 80 \\
\hline \multirow{2}{*}{$G$} & S & 25.26 & 25.83 & 17.10 & 80 & 4.36 & 5.12 & 1.75 & 80 \\
\hline & PF & 197.64 & 374.94 & 76.00 & 80 & 114.55 & 207.22 & 50.50 & 80 \\
\hline \multirow{2}{*}{ Control } & $S$ & $<\mathrm{DL}$ & - & $<\mathrm{DL}$ & 24 & 0.23 & 0.33 & 0.05 & 24 \\
\hline & PF & $<\mathrm{DL}$ & - & $<\mathrm{DL}$ & 24 & 0.68 & 0.72 & 0.40 & 24 \\
\hline
\end{tabular}

*SD: Standard deviation; S: Synthetic Saliva; PF: Artificial Plaque Fluid; $<$ DL: Bellow detection limits $\left(2.78 \mu \mathrm{g} \mathrm{L}^{-1}\right.$ for Ni and $0.27 \mu \mathrm{g} \mathrm{L^{-1 }}$ for $\mathrm{Cr}_{\text {in }}$ synthetic saliva and $2.77 \mu \mathrm{g} \mathrm{L}^{-1}$ for $\mathrm{Ni}$ and $0.85 \mu \mathrm{g} \mathrm{L}^{-1}$ for $\mathrm{Cr}$ in artificial plaque fluid). 
synthetic saliva and artificial plaque fluid among the different studied brackets and controls are displayed in Table 4.

Graphs 1 to 4 present median values of $\mathrm{Ni}$ and Cr release $\left(\mu \mathrm{g} \mathrm{L}^{-1}\right)$ in synthetic saliva and artificial plaque fluid detected at each week over the experimental time. These graphs do not show a trend toward decrease or increase in metal release from week 1 to week 4 in general.

Artificial plaque fluid samples from the experimental groups presented significantly higher rates of $\mathrm{Ni}$ and $\mathrm{Cr}$ than synthetic saliva samples $(\mathrm{p}<0.001 \%)$. The control group did not present difference between artificial plaque fluid and synthetic saliva samples $(\mathrm{p}=0.950$ for $\mathrm{Ni}$ and 0.585 for $\mathrm{Cr}$ ).

\section{Discussion}

This study has compared the $\mathrm{Ni}$ and $\mathrm{Cr}$ release from 7 groups of different commercially available brackets in simulated oral environments. The amounts of $\mathrm{Ni}$ and $\mathrm{Cr}$ released from brackets were quite different among the groups, and varied ac-

Table 4 - P values obtained from nonparametric multiple comparisons of controls and studied brackets for $\mathrm{Ni}$ and $\mathrm{Cr}$ release $\left(\mu \mathrm{g} \mathrm{L}^{-1}\right)$ in synthetic saliva and artificial plaque fluid.

\begin{tabular}{|c|c|c|c|c|}
\hline \multirow{2}{*}{ Comparison } & \multicolumn{2}{|c|}{ Ni release } & \multicolumn{2}{|c|}{$\mathrm{Cr}$ release } \\
\hline & Saliva & Plaque Fluid & Saliva & Plaque Fluid \\
\hline A \& Control & $<0.001^{*}$ & $<0.001^{*}$ & $<0.001^{*}$ & $<0.001^{*}$ \\
\hline$B \& A$ & $<0.001^{*}$ & $0.001^{*}$ & $0.037^{*}$ & $0.014^{*}$ \\
\hline$B \& C$ & 0.148 & $<0.001^{*}$ & $0.001^{*}$ & $0.001^{*}$ \\
\hline B \& Control & $0.010^{*}$ & $<0.001^{*}$ & $<0.001^{*}$ & $<0.001^{*}$ \\
\hline$C \& A$ & $<0.001^{*}$ & $<0.001^{*}$ & $<0.001^{*}$ & $<0.001^{*}$ \\
\hline C \& Control & 0.109 & $<0.001^{*}$ & 0.106 & $<0.001^{*}$ \\
\hline$D \& A$ & $<0.001^{*}$ & 0.833 & $<0.001^{*}$ & 0.367 \\
\hline$D \& B$ & 0.950 & $0.002^{*}$ & $0.002^{*}$ & $0.001^{*}$ \\
\hline$D \& C$ & 0.166 & $<0.001^{*}$ & 0.765 & $<0.001^{*}$ \\
\hline D \& Control & $0.011^{*}$ & $<0.001^{*}$ & 0.069 & $<0.001^{*}$ \\
\hline$D \& F$ & 0.665 & $<0.001^{*}$ & $<0.001^{*}$ & $<0.001^{*}$ \\
\hline$E \& A$ & $<0.001^{*}$ & 0.224 & $0.025^{*}$ & 0.522 \\
\hline$E \& B$ & $<0.001^{*}$ & 0.036 & 0.878 & 0.068 \\
\hline$E \& C$ & $<0.001^{*}$ & $<0.001^{*}$ & $0.001^{*}$ & $<0.001^{*}$ \\
\hline E \& Control & $<0.001^{*}$ & $<0.001^{*}$ & $<0.001^{*}$ & $<0.001^{*}$ \\
\hline$E \& D$ & $<0.001^{*}$ & 0.315 & $0.003^{*}$ & 0.123 \\
\hline$E \& F$ & $<0.001^{*}$ & $0.003^{*}$ & $0.005^{*}$ & $0.029^{*}$ \\
\hline$E \& G$ & $0.025^{*}$ & $<0.001^{*}$ & 0.187 & $<0.001^{*}$ \\
\hline$F \& A$ & $<0.001^{*}$ & $<0.001^{*}$ & 0.584 & $0.005^{*}$ \\
\hline$F \& B$ & 0.711 & 0.354 & $0.009^{*}$ & 0.722 \\
\hline$F \& C$ & 0.069 & $<0.001^{*}$ & $<0.001^{*}$ & $0.004^{*}$ \\
\hline F \& Control & $0.005^{*}$ & $<0.001^{*}$ & $<0.001^{*}$ & $<0.001^{*}$ \\
\hline$G \& A$ & $<0.001^{*}$ & $<0.001^{*}$ & $<0.001^{*}$ & $<0.001^{*}$ \\
\hline$G \& B$ & $0.047^{*}$ & $<0.001^{*}$ & 0.140 & $<0.001^{*}$ \\
\hline$G \& C$ & $0.001^{*}$ & 0.874 & $0.048^{*}$ & 0.671 \\
\hline G\& Control & $<0.001^{*}$ & $<0.001^{*}$ & $0.003^{*}$ & $<0.001^{*}$ \\
\hline$G \& D$ & $0.040^{*}$ & $<0.001^{*}$ & 0.094 & $<0.001^{*}$ \\
\hline$G \& F$ & 0.105 & $<0.001^{*}$ & $<0.001^{*}$ & $0.001^{*}$ \\
\hline
\end{tabular}

*Statistically significant difference at $\mathrm{P}<0.05$. 
Graph 1 - Median values of $\mathrm{Ni}$ concentration $\left(\mu \mathrm{g} \mathrm{L}^{-1}\right)$ detected in synthetic saliva for controls and studied brackets.

Graph 2 - Median values of $\mathrm{Ni}$ concentration $\left(\mu \mathrm{g} \mathrm{L}^{-1}\right)$ detected in artificial plaque fluid for controls and studied brackets.

Graph 3 - Median values of $\mathrm{Cr}$ concentration $\left(\mu \mathrm{g} \mathrm{L}^{-1}\right)$ detected in synthetic saliva for controls and studied brackets.

Graph 4 - Median values of $\mathrm{Cr}$ concentration $\left(\mu \mathrm{g} \mathrm{L}^{-1}\right)$ detected in artificial plaque fluid for controls and studied brackets.
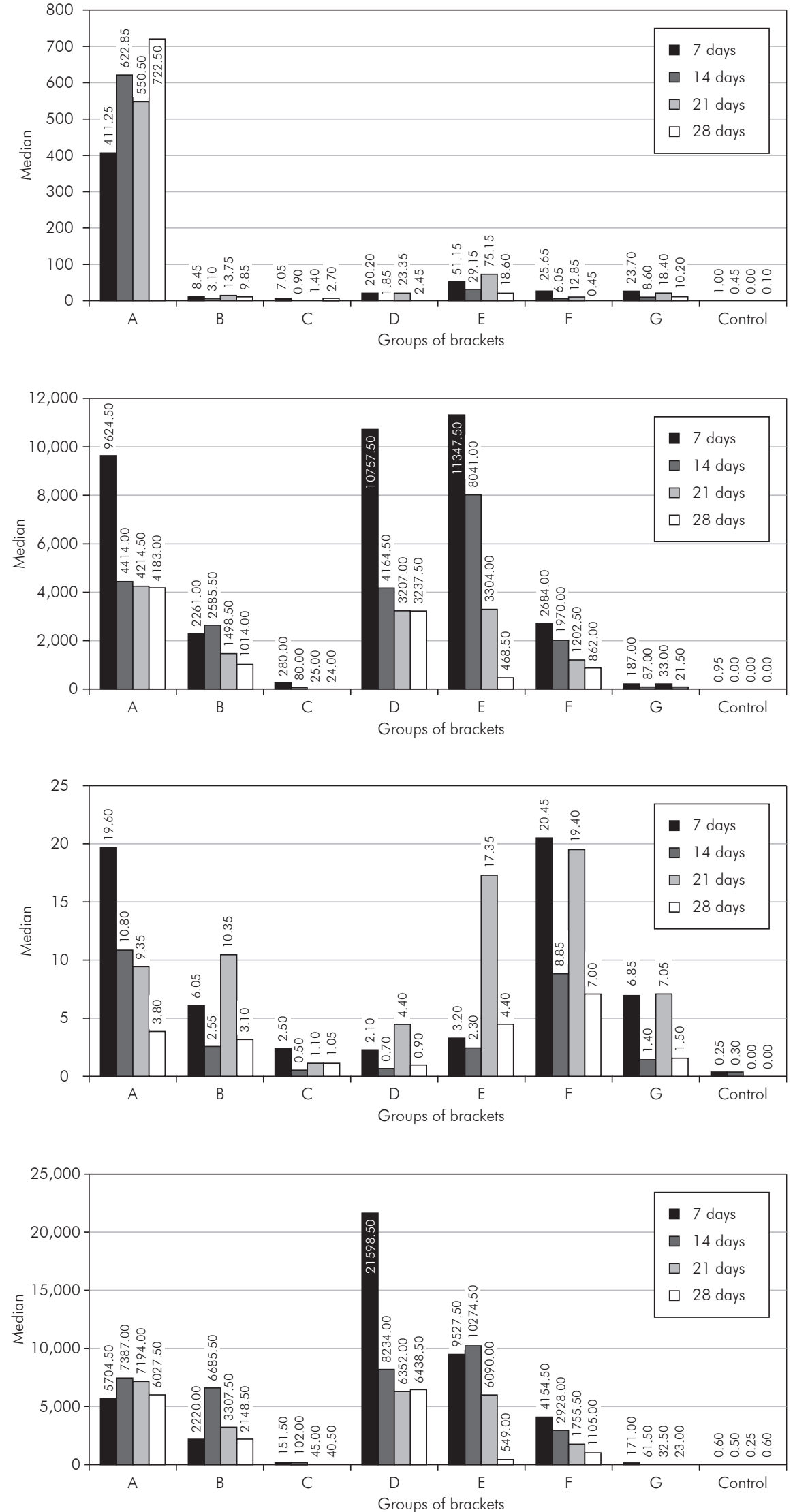
cording to the studied metal ( $\mathrm{Ni}$ or $\mathrm{Cr}$ ) or the immersion medium.

Results exhibited high standard deviation and variance values, which seems to be a sample characteristic, also found by Barrett et al. ${ }^{15}$ (1993) and Eliades et al. ${ }^{16}$ (2004). However, it was possible to find statistical differences between the groups since the amounts of $\mathrm{Ni}$ and $\mathrm{Cr}$ release were quite different. The sample size was determined in compliance with ISO 10271/2001. ${ }^{13}$ Additionally, this study used a sample size even larger than the sample size used by other in vitro studies that measured metal release. ${ }^{15-18}$

A direct comparison between the values obtained in this study and those obtained in other studies cannot be made since different methodologies were applied or different variables were tested. Barrett et al. ${ }^{15}$ (1993), Hwang et al. ${ }^{19}$ (2001) and Shin et al..$^{20}$ (2003) have tested complete orthodontic appliances immersed in different synthetic saliva formulas. Staffolani et al..$^{18}$ (1999) tested orthodontic appliances immersed in organic and inorganic acids. Eliades et al. ${ }^{16}$ (2004), Huang et al. ${ }^{21}$ (2001) and Huang et al..$^{22}$ (2004) observed smaller values of metal release than this study. However, these studies all used different immersion solutions, and did not include solutions replaced weekly, which may have caused a saturation of the immersion medium, decreasing $\mathrm{Ni}$ and Cr release. Platt et al. ${ }^{9}$ (1997) tested different alloys, fragments of 2205 and 316L stainless steel, but not orthodontic brackets. Kuhta et al. ${ }^{23}$ (2009) tested metal ion release from simulated orthodontic appliances with different types of archwires, and observed that the type of archwire can also influence the release of ions.

The A brackets presented the highest amounts of $\mathrm{Ni}$ release in artificial saliva, and the $\mathrm{C}$ brackets presented the least. The $\mathrm{F}$ brackets, made of Co$\mathrm{Cr}$ wear-resistant alloy with the least $\mathrm{Ni}$ content $(0.5 \%),{ }^{11}$ did not release the least amounts of $\mathrm{Ni}$. This corrosion behavior of the $\mathrm{F}$ brackets can be explained by the characteristics exhibited by the CoCr wear-resistant alloy with low nickel content (3\% max.) in aqueous medium. According to the Key to Metals Database, ${ }^{11}$ even though this alloy possesses some resistance to aqueous corrosion, it is limited by grain boundary carbide precipitation, as well as by the lack of vital alloying elements in the matrix, after formation of the carbides, and by chemical segregation in the microstructure. These characteristics are important and clinically relevant.

Comparing Victory ${ }^{\mathrm{TM}}$ and Full Size ${ }^{\mathrm{TM}}$ from Unitek $^{\mathrm{TM}}$, it was evident that different models from the same manufacturer may exhibit different rates of $\mathrm{Ni}$ and $\mathrm{Cr}$ release.

Graphs 1 to 4 did not present a trend toward increasing or decreasing rates of $\mathrm{Ni}$ and $\mathrm{Cr}$ release over the experimental period. Defining a pattern of $\mathrm{Ni}$ and $\mathrm{Cr}$ release over time was not an objective of this study as it would be necessary to conduct a long term study for that. Wataha, Lockwood ${ }^{24}$ (1998), which evaluated metal release from alloys in cell culture over 10 months, detected metal release during the whole experiment. Barrett et al..$^{15}$ (1993) observed a decrease in Ni release over 28 days, and a variation in Cr release during the study. Grimsdottir et al. ${ }^{17}$ (1992) performed immersion tests for 14 days, and Sfondrini et al. ${ }^{25}$ (2009) performed them for 120 hours, although ISO 10271/2001' determines a minimum observation period of 28 days.

Our results showed that the artificial plaque fluid caused a significantly higher rate of $\mathrm{Ni}$ and $\mathrm{Cr}$ release than artificial saliva. This finding agrees with the findings of other studies. ${ }^{18,21-23}$ It also reinforces the necessity of appropriate oral hygiene to minimize corrosion rates.

Further in vivo studies are necessary to determine the clinical implications of the findings of this study.

\section{Conclusion}

Based on the results of the present investigation, which have compared the amounts of $\mathrm{Ni}$ and Cr released from commercially available brackets, it was concluded that corrosive behavior was different among the various bracket models from different manufacturers. Increasing rates of $\mathrm{Ni}$ and $\mathrm{Cr}$ release from the studied brackets were observed in the following order: C, G, B, F, D, E and A. 


\section{References}

1. Grimsdottir MR, Hensten-Pettersen A, Kullmann A. Cytotoxic effect of orthodontic appliances. Eur J Orthod. 1992;14(1):47-53.

2. Bumgardner JD, Lucas LC. Cellular response to metallic ions released from nickel-chromium dental alloys. J Dent Res. 1995;74(8):1521-7.

3. Sakai T, Takeda S, Nakamura M. The effects of particulate metals on cell viability of osteoblast-like cells in vitro. Dent Mater J. 2002;21(2):133-46.

4. Kerosuo H, Kullaa A, Kerosuo E, Kanerva L, Hensten-Pettersen A. Nickel allergy in adolescents in relation to orthodontic treatment and piercing of ears. Am J Orthod Dentofacial Orthop. 1996;109(2):148-54.

5. Janson GRP, Dainesi EA, Consolaro A, Woodside DG, Freitas MR. Nickel hypersensitivity reaction before, during, and after orthodontic therapy. Am J Orthod Dentofacial Orthop. 1998;113(6):655-60.

6. Marigo M, Nouer DF, Genelhu MC, Malaquias LC, Pizziolo VR, Costa AS et al. Evaluation of immunologic profile in patients with nickel sensitivity due to use of fixed orthodontic appliances. Am J Orthod Dentofacial Orthop. 2003;124(1):4652.

7. Faccioni F, Franceschetti P, Cerpelloni M, Fracasso ME. In vivo study on metal release from fixed orthodontic appliances and DNA damage in oral mucosa cells. Am J Orthod Dentofacial Orthop. 2003;124(6):687-93.

8. International Agency for Research on Cancer. Chromium, nickel and welding. Lyon: International Agency for Research on Cancer; 1990. 667 p.

9. Platt JA, Guzman A, Zuccari A, Thornburg DW, Rhodes BF, Oshida Y et al. Corrosion behavior of 2205 duplex stainless steel. Am J Orthod Dentofacial Orthop. 1997;112(1):69-79.

10. Maijer R, Smith DC. Biodegradation of the orthodontic bracket system. Am J Orthod Dentofacial Orthop. 1986;90(3):1958.

11. Key to Metals: nonferrous [database on the Internet]. Cobalt and cobalt alloys [cited 2008 Abr 19]. Available from: http:// www.key-to-nonferrous.com/Print.aspx?id=CheckArticle $\circlearrowleft L N=E N \mho N M=54$ Print. asp $x ? i d=$ CheckArticle $\sigma L N=E$ $N \& N M=54$.

12. McLaughlin RP, Bennett JC, Trevisi HJ. Systemized orthodontic treatment mechanics. Edinburgh: Mosby; 2001.
13. International Standard Organization. ISO 10271: Dental metallic materials: corrosion test methods. Genebra: ISO; 2001.

14. Leung VWH, Darvell BW. Calcium phosphate system in saliva-like media. J Chem Soc Faraday Trans. 1991;87(11):175964.

15. Barrett RD, Bishara SE, Quinn JK. Biodegradation of orthodontic appliances. Part I. Biodegradation of nickel and chromium in vitro. Am J Orthod Dentofacial Orthop. 1993;103(1):8-14.

16. Eliades T, Pratsinis H, Kletsas D, Eliades G, Makou M. Characterization and cytotoxicity of ions released from stainless steel and nickel-titanium orthodontic alloys. Am J Orthod Dentofacial Orthop. 2004;125(1):24-9.

17. Grimsdottir MR, Gjerdet NR, Hensten-Pettersen A. Composition and in vitro corrosion of orthodontic appliances. Am J Orthod Dentofacial Orthop. 1992;101(6):525-32.

18. Staffolani N, Damiani F, Lilli C, Guerra M, Staffolani NJ, Belcastro $\mathrm{S}$ et al. Ion release from orthodontic appliances. J Dent. 1999;27(6):449-54.

19. Hwang CJ, Shin JS, Cha JY. Metal release from simulated fixed orthodontic appliances. Am J Orthod Dentofacial Orthop. 2001;120(4):383-91.

20. Shin JS, Oh KT, Hwang CJ. In vitro surface corrosion of stainless steel and NiTi orthodontic appliances. Aust Orthod J. 2003;19(1):13-8.

21. Huang TH, Yen CC, Kao CT. Comparison of ion release from new and recycled orthodontic brackets. Am J Orthod Dentofacial Orthop. 2001;120(1):68-75.

22. Huang TH, Ding SJ, Yan M, Kao CT. Metal ion release from new and recycled stainless steel brackets. Eur J Orthod. 2004;26(2):171-7.

23. Kuhta M, Pavlin D, Slaj M, Varga S, Lapter-Varga M, Slaj M. Type of archwire and level of acidity: effects on the release of metal ions from orthodontic appliances. Angle Orthod. 2009;79(1):102-10.

24. Wataha JC, Lockwood PE. Release of elements from dental casting alloys into cell-culture medium over 10 months. Dent Mater. 1998;14(2):158-63.

25. Sfondrini MF, Cacciafesta V, Maffia E, Massironi S, Scribante A, Alberti G et al. Chromium release from new stainless steel, recycled and nickel-free orthodontic brackets. Angle Orthod. 2009;79(2):361-7. 